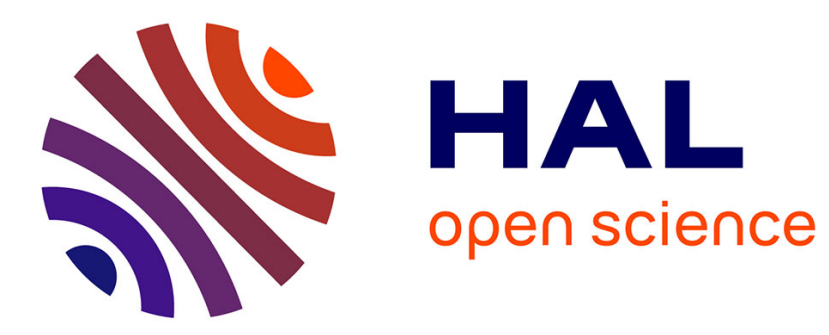

\title{
Electrocoagulation of colloidal biogenic selenium
}

Lucian C. Staicu, Eric D. van Hullebusch, Piet N. L. Lens, Elizabeth A. H.

Pilon-Smits, Mehmet A. Oturan

\section{To cite this version:}

Lucian C. Staicu, Eric D. van Hullebusch, Piet N. L. Lens, Elizabeth A. H. Pilon-Smits, Mehmet A. Oturan. Electrocoagulation of colloidal biogenic selenium. Environmental Science and Pollution Research, 2015, 22 (4), pp.3127-3137. 10.1007/s11356-014-3592-2 . hal-01066500

\section{HAL Id: hal-01066500 https://hal.science/hal-01066500}

Submitted on 21 Sep 2014

HAL is a multi-disciplinary open access archive for the deposit and dissemination of scientific research documents, whether they are published or not. The documents may come from teaching and research institutions in France or abroad, or from public or private research centers.
L'archive ouverte pluridisciplinaire HAL, est destinée au dépôt et à la diffusion de documents scientifiques de niveau recherche, publiés ou non, émanant des établissements d'enseignement et de recherche français ou étrangers, des laboratoires publics ou privés. 


\section{Environmental Science and Pollution Research Electrocoagulation of colloidal biogenic selenium --Manuscript Draft--}

Manuscript Number:

Full Title:

Electrocoagulation of colloidal biogenic selenium

Article Type:

Research Article

Keywords:

Elemental selenium; Colloids; Electrocoagulation; Aluminum electrodes; Iron electrodes; TCLP

Corresponding Author:

Mehmet A. Oturan

Université Paris-Est

Marne-la-Vallée, FRANCE

Corresponding Author Secondary

Information:

Corresponding Author's Institution:

Université Paris-Est

Corresponding Author's Secondary

Institution:

First Author:

Lucian Staicu, PhD student

First Author Secondary Information:

Order of Authors:

Lucian Staicu, PhD student

Eric D. van Hullebusch, Dr.

Piet N.L. Lens, Prof.

Elisabeth A.H. Pilon-Smits, Dr.

Mehmet A. Oturan

Order of Authors Secondary Information:

\begin{tabular}{|c|c|}
\hline Abstract: & $\begin{array}{l}\text { Colloidal elemental selenium, } \mathrm{Se}(0) \text {, adversely affects membrane separation } \\
\text { processes and aquatic ecosystems. As a solution to this problem we investigated for } \\
\text { the first time the removal potential of } \mathrm{Se}(0) \text { by electrocoagulation process. Colloidal } \\
\mathrm{Se}(0) \text { was produced by a strain of Pseudomonas fluorescens and showed limited } \\
\text { gravitational settling. Therefore, iron (Fe) and aluminum (Al) sacrificial electrodes were } \\
\text { used in a batch reactor under galvanostatic conditions. The best Se(0) turbidity } \\
\text { removal }(97 \%) \text { was achieved using iron electrodes at } 200 \mathrm{~mA} \text {. Aluminum electrodes } \\
\text { removed } 96 \% \text { of colloidal } \mathrm{Se}(0) \text { only at a higher current intensity }(300 \mathrm{~mA}) \text {. At the best } \\
\mathrm{Se}(0) \text { removal efficiency, electrocoagulation using Fe electrode removed } 93 \% \text { of the } \\
\mathrm{Se} \text { concentration, whereas with Al electrodes the Se removal efficiency reached only } \\
54 \% \text {. Due to the less compact nature of the Al flocs, the Se-Al sediment was three } \\
\text { times more voluminous than the Se-Fe sediment. The TCLP test showed that the Fe- } \\
\text { Se sediment released Se below the regulatory level }(1 \mathrm{mg} \mathrm{L}-1) \text {, whereas the Se } \\
\text { concentration leached from the Al-Se sediment exceeded the limit by about } 20 \text { times. } \\
\text { This might be related to the mineralogical nature of the sediments. Electron scanning } \\
\text { micrographs showed Fe-Se sediments with a reticular structure, whereas the Al-Se } \\
\text { sediments lacked an organized structure. Overall, the results obtained showed that the } \\
\text { use of Fe electrodes as soluble anode in electrocoagulation constitutes a better option } \\
\text { than Al electrodes for the electrochemical sedimentation of colloidal Se(0). }\end{array}$ \\
\hline \multirow[t]{3}{*}{ Suggested Reviewers: } & $\begin{array}{l}\text { Manuel A. Rodrigo, Prof. } \\
\text { Universidad de Castilla-La Mancha, Spain } \\
\text { Manuel.Rodrigo@uclm.es }\end{array}$ \\
\hline & $\begin{array}{l}\text { Subramanyan Vasudevan, Dr. } \\
\text { Central electrochemical Research Institute, India } \\
\text { vasudevan65@gmail.com }\end{array}$ \\
\hline & Yusuf Yavuz, Prof. \\
\hline
\end{tabular}


Anadolu University, Turkey

yuyavuz@anadolu.edu.tr

Hui Zhang, Prof.

Wuhan University, China

eeng@whu.edu.cn

Opposed Reviewers: 


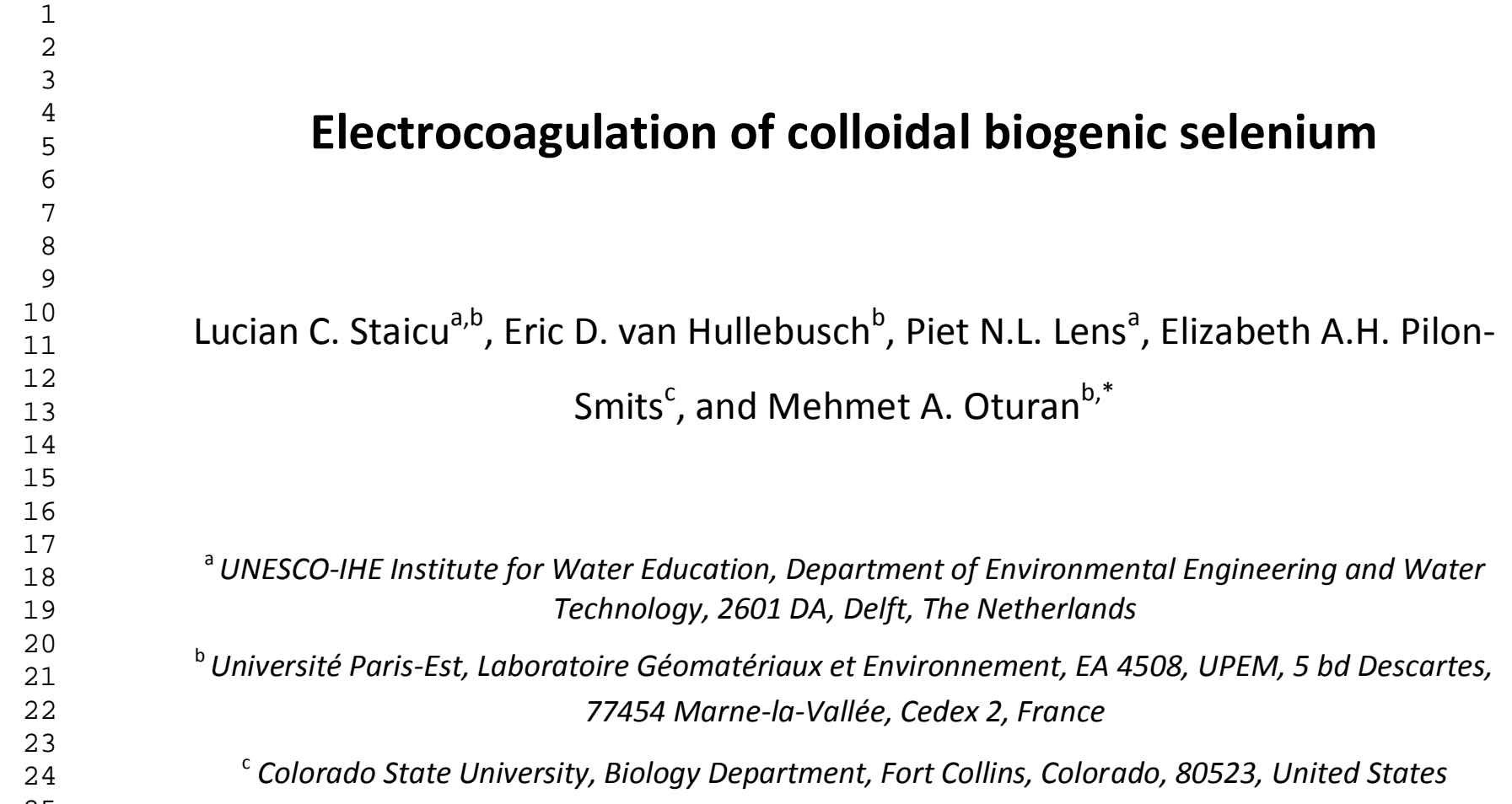

\section{Electrocoagulation of colloidal biogenic selenium}

\author{
Lucian C. Staicu ${ }^{a, b}$, Eric D. van Hullebusch ${ }^{b}$, Piet N.L. Lens ${ }^{a}$, Elizabeth A.H. Pilon- \\ Smits ${ }^{c}$, and Mehmet A. Oturan ${ }^{b}{ }^{*}$ \\ ${ }^{a}$ UNESCO-IHE Institute for Water Education, Department of Environmental Engineering and Water \\ Technology, 2601 DA, Delft, The Netherlands \\ ${ }^{\mathrm{b}}$ Université Paris-Est, Laboratoire Géomatériaux et Environnement, EA 4508, UPEM, 5 bd Descartes, \\ 77454 Marne-la-Vallée, Cedex 2, France \\ ${ }^{c}$ Colorado State University, Biology Department, Fort Collins, Colorado, 80523, United States
}

\section{Paper submitted to: Environmental Science and Pollution Research}

*Corresponding author:

Tel: +33149329065

E-mail: Mehmet.Oturan@univ-paris-est.fr (Mehmet A. Oturan) 


\section{Highlights}

- Colloidal $\mathrm{Se}(0)$ suspensions were sedimented by electrocoagulation for the first time

- Fe and Al electrodes achieved up to $97 \%$ turbidity removal at 200 and $300 \mathrm{~mA}$, respectively

- The energy consumption for $97 \%$ turbidity removal is below $1.68 \mathrm{kWh} \mathrm{m}^{-3}$ at lower currents

- The TCLP test indicates that the Se-Fe sediment meets the regulatory limit for Se 
Colloidal elemental selenium, Se(0), adversely affects membrane separation processes and aquatic ecosystems. As a solution to this problem we investigated for the first time the removal potential of $\mathrm{Se}(0)$ by electrocoagulation process. Colloidal $\mathrm{Se}(0)$ was produced by a strain of Pseudomonas fluorescens and showed limited gravitational settling. Therefore, iron (Fe) and aluminum (Al) sacrificial electrodes were used in a batch reactor under galvanostatic conditions. The best Se(0) turbidity removal (97\%) was achieved using iron electrodes at 200 $\mathrm{mA}$. Aluminum electrodes removed $96 \%$ of colloidal $\mathrm{Se}(0)$ only at a higher current intensity (300 mA). At the best Se(0) removal efficiency, electrocoagulation using Fe electrode removed $93 \%$ of the Se concentration, whereas with Al electrodes the Se removal efficiency reached only $54 \%$. Due to the less compact nature of the Al flocs, the Se-Al sediment was three times more voluminous than the Se-Fe sediment. The TCLP test showed that the Fe-Se sediment released Se below the regulatory level $\left(1 \mathrm{mg} \mathrm{L}^{-1}\right)$, whereas the Se concentration leached from the Al-Se sediment exceeded the limit by about 20 times. This might be related to the mineralogical nature of the sediments. Electron scanning micrographs showed Fe-Se sediments with a reticular structure, whereas the Al-Se sediments lacked an organized structure. Overall, the results obtained showed that the use of Fe electrodes as soluble anode in electrocoagulation constitutes a better option than Al electrodes for the electrochemical sedimentation of colloidal Se(0).

Keywords: Elemental selenium; Colloids; Electrocoagulation; Aluminum electrodes; Iron electrodes; TCLP 


\section{INTRODUCTION}

Selenium (Se) has a complex biogeochemistry with both abiotic and biotic reactions involved in its cycling through different compartments of the environment. The two most oxidized forms, or oxyanions, namely selenite ( $\mathrm{Se}[\mathrm{IV}], \mathrm{SeO}_{3}{ }^{2-}$ ) and selenate (Se[VI], $\mathrm{SeO}_{4}{ }^{2-}$ ), are water-soluble, bioavailable and toxic (Simmons and Wallschlaeger 2005). During the mid1970s, Lake Belews in North Carolina was affected by Se oxyanions released by a coal-fired power plant, which resulted in the massive die-off of the local fish populations: 19 out of 20 species were eliminated (Lemly 2002). In the early 1980s, the Se-laden agricultural drain water discharged in the Kesterson Reservoir, California, severely affected the migratory bird populations and triggered environmental actions (Ohlendorf 1989).

In contrast to its soluble oxyanions, elemental $\mathrm{Se}, \mathrm{Se}(0)$, is particulate and less bioavailable (Lenz and Lens 2009). However, when released into surface waters, Se(0) has been reported to adversely affect bivalve mollusks (Luoma et al. 1992; Schlekat et al. 2000) and to be oxidized to Se oxyanions (Zhang et al. 2004). Because the filter-feeding mollusks are situated at the bottom of the trophic network, their Se content is biomagnified in the higher trophic levels (Chapman et al. 2010). The impact of colloidal elemental Se(0) on bivalve mollusks and trophic networks was investigated extensively in the San Francisco Bay area (Purkerson et al. 2003; Presser and Luoma 2006; EPA 2010; Schlekat et al. 2010). To complicate matters further, biogenic $\mathrm{Se}(0)$ exhibits colloidal properties that make its separation from aqueous solution problematic (Buchs et al. 2013; Staicu et al. 2014a).

Major sources of wastewaters containing selenium oxyanions are oil refining industry, coal combustion and metal refining (Lemly 2004; EPA, 2010). The biological treatment of these wastewaters produces different concentration levels of colloidal Se(0) as a function of the initial Se content and the Se conversion rate. Removal of colloidal Se(0) from the bioreactor effluent is necessary to reduce its environmental load and the negative impact exerted on aquatic ecosystems. 
At the cathode:

$$
2 \mathrm{H}_{2} \mathrm{O}+2 \mathrm{e}^{-} \rightarrow \mathrm{H}_{2}(g)+2 \mathrm{OH}^{-}
$$

In the bulk solution:

$$
\mathrm{M}^{n+}+n \mathrm{OH}^{-} \rightarrow \mathrm{M}(\mathrm{OH}) n(s)
$$

where $M$ is the metal (e.g. Al, Fe) in its elemental form (zero valence state), $\mathrm{M}^{n+}$ is the oxidized metal $(n=2,3)$, ne represents the number of electrons transferred. Due to their proven efficiency and affordable price, Al and Fe electrodes are frequently employed in EC processes. In the case of $\mathrm{Fe}$ anode, the $\mathrm{Fe}^{2+}$ ions are oxidized by dissolved $\mathrm{O}_{2}$ to form $\mathrm{Fe}^{3+}(4)$. The release of polyvalent cations neutralizes the negatively-charged colloidal particles leading to their destabilization and aggregation. In addition, the presence of an electrical field enhances the collision probability and therefore the efficiency of the coagulation process.

Reactions (1) and (4) explain the formation of metallic cations and their hydroxides that react to form hydroxo monomeric and polymeric species. Metal hydroxides have large 


\section{MATERIALS AND METHODS}

\subsection{Reagents and electrodes}

For bacterial growth, King B (KB) medium was prepared as described by King et al. (1954). Sodium selenite, $\mathrm{Na}_{2} \mathrm{SeO}_{3},>99 \%$, was purchased from Sigma Aldrich. Coagulant reagent was generated by the electrodissolution of Al (99\% purity) and Fe (99.5\% purity) electrodes both from Goodfellow Ltd., UK. 
All solutions were prepared using deionized water. Before and after each experiment, the electrodes were degreased by wiping with an acetone-soaked tissue, abraded with sand paper and rinsed with ultrapure water to remove any impurities and oxide layers (Heidmann and Calmano 2010).

\subsection{Biogenic elemental Se production and solution preparation}

Biogenic elemental Se, Se(0), was produced aerobically by a strain of Pseudomonas fluorescens, isolated from the roots of Stanleya pinnata (Brassicaceae), a model Se hyperaccumulator species (Staicu et al. 2014b). The KB medium was supplemented with 10 $\mathrm{mM} \mathrm{Na}_{2} \mathrm{SeO}_{3}$ from a filter-sterilized $1 \mathrm{~mol} \mathrm{~L}^{-1}$ stock solution and with $1 \%(\mathrm{v} / \mathrm{v})$ of $P$. fluorescens inoculum sampled during the mid-logarithmic growth phase. The incubation was performed under aerobic conditions at $28^{\circ} \mathrm{C}, \mathrm{pH}_{0}=7.5$, and $160 \mathrm{rpm}$. After 24 hours, the incubation turned red, indicative of $\mathrm{SeO}_{3}{ }^{2-}$ reduction to red elemental Se (Figure 2b). Elemental Se was harvested by centrifugation (at 3,200 x g for $10 \mathrm{~min}$ ), washed twice with deionized water and re-suspended in $42 \mathrm{mM} \mathrm{NaCl}$ solution (Canizares et al. 2007). The electrolyte addition corresponded to a conductivity of around $4.5 \mathrm{mS} \mathrm{cm}^{-1}$. The turbidity of the solution was adjusted by adding biogenic $\mathrm{Se}(0)$ or $\mathrm{NaCl}$ solution until the desired target value was reached. Due to the colloidal nature of $\mathrm{Se}(0)$ the targeted turbidity value of the suspension was set within $\pm 5 \%$. $\mathrm{NaCl}$ acts as supporting electrolyte.

\subsection{Electrocoagulation set-up}

The coagulating agents were electrogenerated using sacrificial metallic anodes of $\mathrm{Al}$ and Fe, respectively (Fig. 1). The electrochemical experiments were conducted under galvanostatic conditions, i.e. the current was set and the potential adjusted its value as a function of system's resistance. The electrocoagulation experiments were carried out in batch mode in a $500 \mathrm{~mL}$ single compartment electrochemical cell containing colloidal Se(0) suspension and two electrodes (100 mm height $\times 50 \mathrm{~mm}$ width $\times 1 \mathrm{~mm}$ thick in dimension). Both the anode and the cathode are consisting of same metal ( $\mathrm{Al}$ or Fe). The electrodes were connected in a monopolar mode and were placed vertically and parallel to each other. This 
electrode configuration was chosen to minimize the flotation effect of the hydrogen and oxygen gas bubble evolution exerted on the colloidal $\mathrm{Se}(0)$ suspension.

In order to improve the mass transfer, the electrochemical reactor was mixed at 300 rpm using a $3 \mathrm{~cm}$ magnetic stir bar. The electrodes were immersed in the solution up to a 60 $\mathrm{cm}^{2}$ active electrode geometric area with a $3 \mathrm{~cm}$ electrode gap. The constant agitation produced by the magnetic stir bar ensured the homogeneous mass transfer of the coagulant within the electrochemical reactor and increased the collision frequency of colloidal $\mathrm{Se}(0)$ particles with the coagulating agent. Based on a preliminary study (data not shown), we determined the optimal distance to be $3 \mathrm{~cm}$. The distance between electrodes is a critical parameter in the electrochemical cell design since a suboptimal electrode gap increases the IR-drop leading to higher energy consumption (Mollah et al. 2004). The results are presented as average values of three independent experiments (triplicates, $n=3$ ) unless otherwise stated. When the standard deviation values were smaller than $5 \%$, the error bars were not represented. All data was analyzed by using the data analysis software SigmaPlot 12.0v.

\subsection{Electrocoagulant generation}

In order to determine the amount of $\mathrm{Al}$ and $\mathrm{Fe}$ electrogenerated, separate experiments were performed. The $\mathrm{Se}(0)$-free solution contained $42 \mathrm{mM} \mathrm{NaCl}$ and the sampling was done with the same frequency as the EC Se(0) treatment protocol. All samples were acidified with $65 \% \mathrm{HNO}_{3}$ and stored at $4{ }^{\circ} \mathrm{C}$ until elemental analysis was performed on a PerkinElmer Optima 8300 Inductively Coupled Plasma-Optical Emission Spectroscopy (ICPOES). Residual Se, Fe and Al were determined by the same method. Calibration standards were prepared by stepwise dilution of a multi-element ICP standard solution (Merck, Darmstadt, Germany). The wavelengths employed were $196.026 \mathrm{~nm}$ for Se, $238.204 \mathrm{~nm}$ for $\mathrm{Fe}$, and $396.153 \mathrm{~nm}$ for $\mathrm{Al}$, respectively. At the end of the sedimentation stage, the supernatants were carefully siphoned from the sedimentation cones. Both the supernatant and the sediments were collected for further analyses.

\subsection{Toxicity Characteristic Leaching Procedure (TCLP) test}


The sediment samples were analyzed using the TCLP performed according to the testing guidelines specified by the United States Environmental Protection Agency (USEPA 1999). The sediment was mixed in a glacial acetic acid (of $99.5 \%$ assay) solution at $1: 20$ with a final $\mathrm{pH}$ of $2.88 \pm 0.05$. The leachate mixture was sealed in the extraction vessel (plastic centrifuge tubes, $29 \times 115 \mathrm{~mm}, 50 \mathrm{~mL}$ ) and tumbled for 20 hours using a Grant Bio PTR-30 360 Vertical Multi-Function Rotator to simulate an extended leaching time in the ground. The vertical rotation speed employed was $30 \mathrm{rpm}$. After $20 \mathrm{~h}$, the samples were filtered gravitationally through Whatman glass microfiber filters, Grade GF/F (0.7 $\mu \mathrm{m}$ cut-off) and the filtrate analyzed by ICP-OES.

\subsection{Analytical methods}

Turbidity was measured using a HACH 2100P ISO turbidimeter (Hach 2100P ISO) containing a T860 nm LED lamp and was expressed in Nephelometric Turbidity Units (NTU). $15 \mathrm{~mL}$ aliquots were sampled according to the manufacturer's instructions. Electrophoretic mobility measurements were performed on a Zetasizer Nano ZS (Malvern Instrument Ltd., Worchestershire, UK) using a laser beam at $633 \mathrm{~nm}$ and a scattering angle of $173^{\circ}$ at $25^{\circ} \mathrm{C}$ according to the manufacturer's instructions. The volume of settled $\mathrm{Se}(0)$ was measured in standard 1,000 mL Imhoff graduated cones (USEPA 1999).

Environmental scanning electron microscopy (ESEM, ELECTROSCAN E3, Hillsboro, OR, USA) was used for the observation of the microstructure of Se-Fe and Se-Al sediments. ESEM allows the examination of wet specimens without sample preparation (Donald 2003). The samples were observed at $25 \mathrm{kV}$. X-ray diffraction (XRD) analysis was performed on a Bruker D8 Advance diffractometer (Karlsruhe, Germany) equipped with an energy dispersion Sol-X detector with copper radiation (CuK $\alpha, \lambda=0.15406 \mathrm{~nm}$ ). The acquisition was recorded between $10^{\circ}$ and $80^{\circ}$, with a $0.02^{\circ}$ scan step and $1 \mathrm{~s}$ step time.

pH was measured by an EUTECH $1500 \mathrm{pH}$ meter. Conductivity measurements were performed on a Radiometer Analytical MeterLab CDM 230. The electrical current was applied 
and the evolution of the current and voltage was monitored using a HAMEG Triple Power HM7042-5 (Mainhausen, Germany).

\subsection{Calculations}

The specific electrical energy consumption $E\left(\mathrm{kWh} \mathrm{m}^{-3}\right)$ for turbidity removal was calculated as follows (Heidmann and Calmano 2010):

$$
E=\frac{U \cdot I \cdot t}{V \cdot 1000}
$$

where $U$ is the required voltage $(\mathrm{V}), I$ the applied current $(\mathrm{A}), t$ electrolysis time $(\mathrm{h})$ and $V$ the volume of the treated solution $\left(\mathrm{m}^{3}\right)$.

The maximum possible mass of $\mathrm{Al}$ and Fe electrochemically generated from sacrificial anodes for a particular electrical current was calculated using Faraday's law of electrolysis (Mechelhoff et al. 2013):

$$
m=\frac{j \cdot A e l \cdot M \cdot t}{V \cdot z \cdot F}
$$

where $m$ is the mass of the anode material dissolved $(\mathrm{g}), j$ the current density $\left(\mathrm{A} \mathrm{m}^{-2}\right), A e l$ the active electrode area $\left(\mathrm{m}^{2}\right), M$ the molar mass of the anode material $\left(\mathrm{g} \mathrm{mol}^{-1}\right), t$ electrolysis time $(\mathrm{s}), V$ volume of the reactor $\left(\mathrm{m}^{3}\right), z$ the number of electrons transferred, and $F$ the Faraday's constant $\left(96,485 \mathrm{C} \mathrm{mol}^{-1}\right)$. The cathode dissolution was not considered.

\section{RESULTS AND DISCUSSION}

\subsection{Characterization of the biogenic $\mathrm{Se}(0)$ suspension}

The properties of the biogenic red $\mathrm{Se}(0)$ solution (Fig. $2 \mathrm{~b}$ ) are summarized in Table 1. The suspension is characterized by high turbidity and neutral $\mathrm{pH}$. The $\mathrm{Se}(0)$ particles exhibit a negative surface charge of around $-20 \mathrm{mV}$. 
The colloidal stability of biogenic Se(0) is presented in Fig. 2a. Biogenic Se(0) displayed insignificant sedimentation during the 4-day study interval, from 500 NTU to 420 NTU, corresponding to a normalized removal of 0.16 . Note that turbidity was normalized against its initial value using a scale from 0 to 1 (1 represents no sedimentation, 0 represents total sedimentation of the colloidal system). The colloidal stability of $\mathrm{Se}(0)$ is related to the negatively-charged biopolymers that are coating the biogenic selenium particles (Dobias et al. 2011; Buchs et al. 2013).

\subsection{Electrodissolution of the $\mathrm{Al}$ and Fe electrodes}

Figure 3 compares the variation the concentrations of electrogenerated $\mathrm{Al}$ and $\mathrm{Fe}$ measured with respect to the electrical charge passed. For both electrodes, the metal concentration increases linearly with the electrical charge. For both electrodes, the metal concentration increases linearly with the electrical charge. The measured values exceed the predicted values calculated from Eq. (6), i.e. a super-faradaic yield is obtained. In the case of $\mathrm{Al}$, the difference is negligible, whereas the Fe anode exhibits 1.3 times higher measured concentrations than the theoretically expected ones. Even if Fe has a higher redox potential $(-0.44 \mathrm{~V})$ than $\mathrm{Al}(-1.67 \mathrm{~V})$, the formation of an Al oxide layer during electrolysis coats the electrode surface, thus decreasing its corrosion potential (Roberge 2008).

The super-faradaic yield exhibited by the Fe electrodes could be explained by the difference between the electrode's geometric area and the actual area that takes into account the surface roughness. Electrocoagulation is corroding the sacrificial anodes, thus increasing their surface area as a function of the anode material, current applied and the corrosiveness of the solution (Roberge 2008). An alternative explanation considers the additional chemical dissolution of the Fe anode (Canizares et al. 2005) due to corrosion. In addition, Picard et al. (2000) reported cathodic dissolution as a consequence of the chemical attack by the hydroxyl ions released during water electrolysis. However, they used a very high conductivity $\left(0.6 \mathrm{~mol} \mathrm{~L}^{-1} \mathrm{NaCl}\right)$ and the currents used were 200 times higher than those applied in the current study. 


\subsection{Treatment efficiency of electrocoagulation}

\subsubsection{Turbidity removal}

Figure 4a compares the turbidity removal using Fe and $\mathrm{Al}$ anodes as a function of the current intensity. For the first two current values applied (50 and $100 \mathrm{~mA}$ ), the Al electrodes produced a slightly higher turbidity removal than the Fe electrodes. At 50 and $100 \mathrm{~mA}$, the $\mathrm{Al}$ electrodes removed $71 \%$ and $86 \%$ of the initial turbidity, whereas the Fe electrodes achieved $69 \%$ and $81 \%$, respectively. In contrast, Fe electrodes lead to a better turbidity removal at higher applied current intensity values. For example, when increasing the current to $200 \mathrm{~mA}$, the Fe electrodes produced the highest turbidity removal (97\%). At the same current, $\mathrm{Al}$ generated only $88 \%$ turbidity removal. Above $200 \mathrm{~mA}$, the electrodes displayed different trends. While turbidity removal by the Fe electrodes remained almost constant at around 97\% for $300 \mathrm{~mA}$ and $500 \mathrm{~mA}$, Al showed the highest performance at $300 \mathrm{~mA}$, with $96 \%$ removal efficiency, followed by $95 \%$ removal at $500 \mathrm{~mA}$. Overall, these results indicate a plateau above $200 \mathrm{~mA}$ for the Fe electrodes and above $300 \mathrm{~mA}$ for the Al electrodes.

Because colloids and electrically-charged ions are held in suspension due to the electrostatic repulsion forces, the presence of counter ions brings about neutralization of the electric charge and diminishes their colloidal stability (Khandegar and Saroha 2013). On the other hand, when liberated in the bulk solution, the metal cations hydrolyze spontaneously by forming a series of metastable hydrolysis products that transit towards thermodynamically stable metal hydroxides (Richens 1997). Destabilized colloidal particles are adsorbed onto metal (oxy)hydroxides or followed by precipitation (Hanai and Hasar 2011). As a consequence of these mechanisms, the colloids aggregate and settle down.

The relation between the current applied and the turbidity removal was not linear (Fig 4a). This indicates a decrease of current efficiency during the electrolysis time, either due to parasitic reactions that are enhanced with the increase of the applied current or to the formation of a passivation layer. Since the temperature measured during the experiments increased only marginally (less than $0.5^{\circ} \mathrm{C}$ ) compared to the beginning of the experiment, 
the Joule effect (i.e. heating induced by the increase of the applied current) seems not to play an important role (Kabdasli et al. 2013). Passivation of the electrode surface has been shown to affect the performance of the process (Mouedhen et al. 2008; Lakshmanan et al. 2009). Because the highest removal efficiencies were recorded at the beginning of the plateau, no further experiments were performed at currents above $500 \mathrm{~mA}$.

$\mathrm{pH}$ is an important factor that influences the speciation of Fe and Al during the process (Mollah et al. 2001). Figure 4b shows the $\mathrm{pH}$ evolution during electrolysis time as a function of the applied current. All experiments started at a $\mathrm{pH}$ value of $7.0 \pm 0.2$. For each current intensity tested, the Fe electrodes induced a higher $\mathrm{pH}$ increase than the $\mathrm{Al}$ ones. It is important to note that the $\mathrm{pH}$ has an important contribution to the formation of $\mathrm{Fe}$ and $\mathrm{Al}$ hydroxides. During experiments with Fe electrodes, the net increase of $\mathrm{pH}$ for all current densities resulted in the formation of dark-colored sediments indicative of the presence of ferric hydroxide deposits (results not shown).

Several mechanisms of colloidal particles destabilization and sedimentation have been proposed (Duan and Gregory 2003). Turbidity removal by sweep flocculation acts by entrapping and bridging the colloids in a floc with the subsequent sedimentation (Mollah et al. 2004). In addition, charge repression of the electrical double layer of the colloidal particles can play a role by diminishing the repulsion potential between likely-charged particles. As a consequence, the particles clump together and settle (Duan and Gregory 2003). Based on the evolution of the $\mathrm{pH}$ during EC experiments, it is likely that sweep flocculation had an important contribution to the overall sedimentation process.

In a previous study (Staicu et al. 2014a) we showed that biogenic Se(0) produced by an anaerobic mixed microbial culture exhibits high colloidal stability that can be repressed by using metal hydrolyzing salts in a chemical coagulation (CC) approach. The biogenic Se(0) suspension used in the two studies had difference sources (pure Pseudomonas versus mixed anaerobic microbial cultures). In addition, the two suspensions displayed different characteristics: the biogenic $\mathrm{Se}(0)$ suspension produced by the mixed culture had a 300 NTU 
higher turbidity and zeta potential of $-23 \pm 3 \mathrm{mV}$ at $\mathrm{pH} 7.0$, the $\mathrm{pH}$ decreased with the addition of metallic salts from $\mathrm{pH} 8$ to 7 , and the solution contained by-products of bacterial metabolism. It is interesting to note though that the chemical dosing study (Staicu et al. 2014a) indicate maximum turbidity removal efficiencies at metal ion doses significantly lower than those electrogenerated in EC. In the case of treatment with Al salts, $0.12 \mathrm{mg} \mathrm{L}^{-1} \mathrm{Al}$ dosed as aluminum sulfate achieved $92 \%$ turbidity removal, while in EC, the maximum turbidity removal of $96 \%$ was obtained by electrogenerating $420 \mathrm{mg} \mathrm{L}^{-1} \mathrm{Al}$. On the other hand, for treatment with Fe salts, $0.167 \mathrm{mg} \mathrm{L}^{-1}$ were need in CC to achieved $43 \%$ turbidity removal, versus $200 \mathrm{mg} \mathrm{L}^{-1}$ of electrogenerated Fe induced $97 \%$ turbidity removal. Metal speciation as a function of $\mathrm{pH}$, as well as the floc growth and the interaction between metals and biopolymers and organic molecules could explain the differences between the performances of the two approaches (Holt et al. 2002).

\subsubsection{TCLP and supernatant characterization}

Leaching tests of the electrogenerated $\mathrm{Al}$ and Fe sediments were conducted following the TCLP method (US EPA Method 1311). The sediments generated by $50 \mathrm{~mA}$ and $100 \mathrm{~mA}$ currents were investigated in terms of the amount of Se, Fe and $\mathrm{Al}$ released from the sediment matrix. Figure 5a presents the TCLP results of Se-Fe and Se-Al sediment samples. At $50 \mathrm{~mA}$, the Se-Al sediment released 5 times more Se than the Se-Fe sample, $16 \mathrm{mg} \mathrm{L}^{-1}$ versus $3 \mathrm{mg} \mathrm{L}^{-1}$. When doubling the applied current, the difference between the Se released by the two sediments increased 22 times: $17.8 \mathrm{mg} \mathrm{L}^{-1}$ versus $0.8 \mathrm{mg} \mathrm{L}^{-1}$. Only the Se concentration of the leachate from the Se-Fe sediment generated at $100 \mathrm{~mA}$ complied with the $1 \mathrm{mg} \mathrm{L}^{-1} \mathrm{EPA}$ regulatory limit (US EPA Method 1311).

$\mathrm{Al}-\mathrm{Se}$ and Fe-Se sediments showed different leaching behavior of $\mathrm{Al}$, Fe and $\mathrm{Se}$, respectively. At $50 \mathrm{~mA}$, the concentration of $\mathrm{Al}$ released was two-fold higher than the Fe concentration, whereas at $100 \mathrm{~mA}$ the Al concentration was slightly inferior compared to the Fe concentration. Fe and Al are not TCLP-regulated elements (US EPA Method 1311 Chapter 7). The stability of sediments over time is an open question related to the validity of the TCLP 
approach as a tool for the sound characterization of the leaching potential of sediments to be landfilled.

Residual turbidity (Fig. 4a) is an important parameter in wastewater treatment. Low residual turbidity is desirable from a technological and ecotoxicological standpoint. The lowest turbidity achieved by the Fe electrodes was 16 NTU for $200 \mathrm{~mA}$. The Al electrodes achieved a minimum residual turbidity of 22 NTU at $300 \mathrm{~mA}$. While in chemical coagulation, the addition of the coagulant is a discrete event and the system shifts towards a final equilibrium state, in EC the equilibrium is constantly moving. Therefore, trying to determine the turbidity removal kinetics in EC is challenging because of the concomitant formation of metal hydroxides during electrolysis that add to the overall turbidity (Holt et al. 2002).

Residual Se (total selenium) remaining in the supernatant after the liquid-solid phase separation is presented in Fig. 5b. The initial Se concentration of the colloidal Se(0) solution (500 $\pm 30 \mathrm{NTU}$ ) was $310 \pm 12 \mathrm{mg} \mathrm{L}^{-1}$. Residual Se (total) varies with the current intensity and the electrode type used. For all current intensities, the Fe electrode as sacrificial anode is more efficient in Se removal than the Al electrode. The minimum Se concentration (141.6 mg $\mathrm{L}^{-1}$ ) in the Al electrode experiment was recorded at $300 \mathrm{~mA}$, corresponding to around $54 \%$ Se reduction. In contrast, at $500 \mathrm{~mA}$ the Fe anode decreased the total Se concentration up to 23 $\mathrm{mg} \mathrm{L}^{-1}$ which corresponds to a Se removal efficiency of around 93\%. By comparing the two electrodes, the Fe was almost 6 times more efficient than Al in total Se removal from analysis of the supernatant of the electrocoagulation cell upon termination of the experiment.

Figure $5 \mathrm{c}$ displays the residual total $\mathrm{Al}$ and $\mathrm{Fe}$ concentrations present in the supernatant at the end of the sedimentation stage. While the Fe concentration decreased with the applied current, from $41 \mathrm{mg} \mathrm{L}^{-1}$ (at $50 \mathrm{~mA}$ ) to $1.26 \mathrm{mg} \mathrm{L}^{-1}$ at $500 \mathrm{~mA}$, the Al concentration showed a limited decrease with the applied current, from $14.2 \mathrm{mg} \mathrm{L}^{-1}$ (at 50 $\mathrm{mA}$ ) to $8.64 \mathrm{mg} \mathrm{L}^{-1}$ (at $500 \mathrm{~mA}$ ). The decrease in Fe concentration can be linked to the decrease in residual Se because Fe (oxy)hydroxides co-precipitate with colloidal $\mathrm{Se}(0)$ and is 
entrapped in the sediment. The higher Se concentration in the Al electrode experiment could also be understood in the same framework.

Secondary pollution refers to pollutants that are not initially present in the wastewater but are introduced during treatment. EC adds the anode-corroded metal to the treated solution. A drawback of using Fe electrodes in EC is related to the residual color (yellowish, green, greenish-black) produced by the dissolution and speciation of Fe (Moreno et al. 2009). It is generally agreed that $\mathrm{Al}$ is not required for proper functioning of biological systems (Gensemer and Playle 1999) and therefore its presence can elicit toxic effects. In contrast, Fe is an essential metabolic component functioning as a cofactor in a wide array of proteins and enzymes (Arredondo and Nunez, 2005). Dong et al. (2014) investigated the Comparative Toxicity Potentials (CTP) of 14 cationic metals, including Al and Fe, in freshwater environments. While Al had one of the highest CTP, Fe ranked among the metals with the lowest CTP. Therefore, from an ecotoxicological standpoint, Fe is a better option for treating colloidal $\mathrm{Se}(0)$ suspensions.

\subsection{Sediment characterization}

To clarify the structure of sediments we carried out ESEM micrographs of Se-Al and Se-Fe sediments. Results obtained are depicted on Fig. 6a and 6b. Se-Al does not appear to have an organized structure. $\mathrm{Se}(0)$ nanoparticles are clearly visible. In contrast, the Se-Fe sediment shows a reticular structure with no observable $\mathrm{Se}(0)$ particles.

X-ray diffraction was performed to investigate the mineralogy of the two types of sediments (Fig. 5c and 5d). Gamage and Chellam (2011) reported that Al sediments generated by EC having an amorphous state and a gelatinous appearance. The same observation was made for our samples (results not shown). The diffractogram of Se-Fe sediments (Fig. 5d) also indicates an amorphous state. This result is in agreement with that reported by Heidmann and Calmano (2010) concerning iron-based sediments generated by EC. 
X-ray diffraction was performed to investigate the mineralogy of the two types of sediments (Fig. 5c and 5d). Gamage and Chellam (2011) reported Al sediments generated by EC having an amorphous state and a gelatinous appearance. The same observation was made for our samples (results not shown). The diffractogram of Se-Fe sediments (Fig. 5d) also indicates an amorphous state. Amorphous iron-based sediments generated by EC were reported by Heidmann and Calmano, 2010.

The properties of Se-Fe and Se-Al sediments generated by electrocoagulation using different currents are summarized in Table 2. On the other side, the evolution of Se-Fe and Se-Al sediment volume as a function of the applied current can be seen in Fig. 6e. While the volume of both Al- and Fe- sediments show a positive trend with the increase in current, the Se-Al sediment becomes more voluminous than Se-Fe by a factor of 2 (at $50 \mathrm{~mA}$ ) to 4.5 (at $500 \mathrm{~mA})$. Because Fe and Al have different densities $\left(7.874\right.$ and $2.70 \mathrm{~g} \mathrm{~cm}^{-3}$ for Fe and Al, respectively) this will impact the floc and eventually sediment structure (Lide 2003; Turchiuli and Fargues 2004). Moreover, higher currents have been shown to increase the bubble densities and create Al flocs with a less compact structure (Holt et al. 2002). Al flocs produced in EC are fragile and relatively porous, therefore prone to breakage (Harif et al. 2012). Smaller flocs thus created are characterized by a poor settleability and voluminous sediment with a porous structure (Harif and Adin 2011). The size of the flocs can play a significant role in settling and solid-liquid separation, as well as in the structure of the sediment (Jarvis et al. 2005).

\subsection{Electrical energy consumption and process optimization}

The electrical energy consumption by the two kinds of electrodes is depicted on Fig. 7. As can be seen in Table 3, for the first three applied currents, 50, 100 and $200 \mathrm{~mA}$, Al and Fe electrodes had almost similar electrical energy consumption (below $1.68 \mathrm{kWh} \mathrm{m}^{-3}$ ). Above $200 \mathrm{~mA}$, at the highest turbidity removal efficiencies, Al electrodes showed a higher energy consumption than Fe $\left(3.42 \mathrm{kWh} \mathrm{m}^{-3}\right.$ versus $\left.1.5 \mathrm{kWh} \mathrm{m}^{-3}\right)$. 


\section{CONCLUSIONS}

From the results obtained in this work the following conclusions can be drawn:

- Biogenic colloidal Se(0) can be effectively separated from aqueous solution by an electrocoagulation process using Fe or Al electrodes.

- Electrocoagulation with Al and Fe sacrificial electrodes (as anode) can achieve high (up to $97 \%$ with) removal efficiencies of colloidal Se(0).

- Low amounts of electrical energy (about $1.68 \mathrm{kWh} \mathrm{m}^{-3}$ at currents below $200 \mathrm{~mA}$ ) are consumed during EC of colloidal Se(0). Al electrodes consume twice the amount of energy required by the Fe electrodes to achieve comparable Se(0) removal efficiencies.

- At the highest colloidal Se(0) removal efficiency, the Fe electrodes are consumed two times faster than the Al electrodes. However, the resulted Se-Al sediment is 3.4 times more voluminous than the Se-Fe sediment.

- The TLCP of Se-Fe sediments suggest that the sediment can be listed as nonhazardous waste, whereas the Se-Al sediment exceeded the TCLP limit for Se by almost 20 times. 


\section{Acknowledgments}

The authors would like to thank the European Commission for providing financial support through the Erasmus Mundus Joint Doctorate Programme ETeCoS ${ }^{3}$ (Environmental Technologies for Contaminated Solids, Soils and Sediments) under the grant agreement FPA $n^{\circ}$ 2010-0009. A special thanks to Dr. David Huguenot and Dr. Rossana Combes for their respective ICP-OES and ESEM expert technical assistance. The analytical part (ICP-OES) was supported by a grant of the Region Ile de France. 


\section{REFERENCES}

Akbal F, Camci S (2011) Copper, chromium and nickel removal from metal plating wastewater by electrocoagulation. Desalination 269(1-3):214-222

Al Aji B, Yavuz Y, Koparal AS (2012) Electrocoagulation of heavy metals containing model wastewater using monopolar iron electrodes. Sep Purif Technol 86:248-254

Arredondo M, Nunez MT (2005) Iron and copper metabolism. Mol Aspects Med 26:313-327

Buchs B, Evangelou MWH, Winkel LHE, Lenz M (2013) Colloidal properties of nanoparticular biogenic Se govern environmental fate and bioremediation effectiveness. Environ Sci Technol 47(5):2401-2407

Canizares P, Carmona M, Lobato J, Martınez F, Rodrigo MA (2005) Electrodissolution of aluminum electrodes in electrocoagulation processes. Ind Eng Chem Res 44:4178-4185

Canizares P, Martınez F, Jimenez, C, Lobato J, Rodrigo MA (2007) Coagulation and electrocoagulation of wastes polluted with colloids. Sep Sci Technol 42:2157-2175

Chapman PM, Adams ML, Brooks CG, Delos SN, Luoma WA, Maher HM, Ohlendorf TS, Presser TS, Shaw DP (2010) Ecological assessment of selenium in the aquatic environments. SETAC Press, Pensacola, Florida, USA

Dobias J, Suvorova El, Bernier-Latmani R (2011) Role of proteins in controlling selenium nanoparticle size. Nanotechnology 22(19):195605

Donald AM (2003) The use of environmental scanning electron microscopy for imaging wet and insulating materials. Nat Mater 2:511-513

Dong Y, Gandhi N, Hauschild MZ (2014) Development of Comparative Toxicity Potentials of 14 cationic metals in freshwater. Chemosphere 112:26-33

Duan J, Gregory J (2003) Coagulation by hydrolyzing metal salts. Adv. Colloid. Interfac. 100$102: 475-502$

Gamage NP, Chellam S (2011) Aluminum electrocoagulation pretreatment reduces fouling during surface water microfiltration. J Membrane Sci 379:97-105

Gensemer RW, Playle RC (1999) The bioavailability and toxicity of aluminum in aquatic environments. Crit Rev Env Sci Technol 29(4):315-450 
Hanai O, Hasar $\mathrm{H}$ (2011) Effect of anions on removing $\mathrm{Cu}^{2+}, \mathrm{Mn}^{2+}$ and $\mathrm{Zn}^{2+}$ in electrocoagulation process using aluminum electrodes. J Hazard Mater 189:572-576

Harif T, Adin A (2011) Size and structure evolution of kaolin-Al(OH) $)_{3}$ flocs in the electroflocculation process: a study using static light scattering. Water Res 45:61956206

Harif T, Khai M, Adin A (2012) Electrocoagulation versus chemical coagulation: Coagulation/flocculation mechanisms and resulting floc characteristics. Water Res 46:3177-3188

Heidmann I, Calmano W (2010) Removal of $\mathrm{Ni}, \mathrm{Cu}$ and $\mathrm{Cr}$ from a galvanic wastewater in an electrocoagulation system with Fe- and Al-electrodes. Sep Purif Technol 71:308-314

Holt PK, Barton GW, Wark M, Mitchell CA (2002) A quantitative comparison between chemical dosing and electrocoagulation. Colloid Surface A 211:233-248

Holt PK, Barton GW, Mitchell CA (2005) The future of electrocoagulation as a localized water treatment technology. Chemosphere 59:335-367

Jarvis P, Jefferson B, Gregory J, Parsons SA (2005) A review of floc strength and breakage. Water Res 39:3121-3137

Kabdasli I, Arslan-Alaton I, Olmez-Hanci T, Tunai O (2012) Electrocoagulation applications for industrial wastewaters: a critical review. Environ Technol Rev 1:2-45

Khandegar V, Saroha AK (2013) Electrocoagulation for the treatment of textile industry effluent - A review. J Environ Manage 128:949-963

King EO, Ward MK, Raney DE (1954) Two simple media for the demonstration of pyocyanin and fluorescein. J Lab Clin Med 44:301-307

Lemly AD (2002) Symptoms and implications of selenium toxicity in fish: the Belews Lake case example. Aquat Toxicol 57(1-2):39-49

Lemly AD (2004) Aquatic selenium pollution is a global environmental safety issue. Ecotox Environ Safe 59:44-56

Lenz, M, Lens PNL (2009) The essential toxin: The changing perception of selenium in environmental sciences. Sci Total Environ 407:3620-3622 
Lenz M, Kolvenbach B, Gygax B, Moes S, Corvinni PFX (2011) Shedding light on selenium biomineralization: proteins associated with bionanominerals. Appl Environ Microb 77(13):4676-4680

Lide, DR (2004) CRC Handbook of Chemistry and Physics, 84th Edition. CRC Press. Boca Raton, Florida

Luoma SN, Johns C, Fisher NS, Steinberg NA, Oremland RS, Reinfelder JR (1992) Determination of selenium bioavailability to a bivalve from particulate and solute pathways. Environ Sci Technol 26:485-491

Mechelhoff M, Kelsall GH, Graham NJD (2013) Super-faradaic charge yields for aluminum dissolution in neutral aqueous solutions. Chem Eng Sci 95:353-359

Mello Ferreira A, Marchesiello M, Thivel PX (2013) Removal of copper, zinc and nickel present in natural water containing $\mathrm{Ca}^{2+}$ and $\mathrm{HCO}_{3}{ }^{-}$ions by electrocoagulation. Sep Purif Technol 107:109-117

Mollah MYA, Schennach R, Parga J, Cocke DL (2001) Electrocoagulation (EC) - science and applications. J Hazard Mater B84:29-41

Mollah MYA, Morkovsky P, Gomes JAG, Kesmez M, Parga J, Cocke DL (2004) Fundamental, present and future perspectives of electrocoagulation. J Hazard Mater 114:199-210

Moreno CHA, Cocke DL, Gomes JAG, Morkovsky P, Parga JR, Peterson E, Garcia C (2009) Electrochemical reactions for electrocoagulation using iron electrodes. Ind Eng Chem Res, $48: 2275-2282$

Mouedhen G, Feki M, Wery MDP, Ayedi HF (2008) Behavior of aluminum electrodes in electrocoagulation process. J Hazard Mater 150:124-135

Ohlendorf HM (1989) Bioaccumulation and effects of selenium in wildlife. In Jacobs LM (ed) Selenium in agriculture and the environment. Am S Agron S Sci. Madison, Wisconsin, series number 23, pp 133-177

Öncel MS, Muhcu A, Demirbas E, Kobya M (2013) A comparative study of chemical precipitation and electrocoagulation for treatment of coal acid drainage wastewater. J Environ Chem Eng 1:989-995 
Picard T, Cathalifaud-Feuillade G, Mazet M, Vandensteendam C (2000) Cathodic dissolution in the electrocoagulation process using aluminium electrodes. J Environ Monit 2:77-80

Presser TS, Luoma SN (2006) Forecasting selenium discharges to the San Francisco Bay-Delta Estuary: Ecological effects of a proposed San Luis Drain extension: U.S. Geological Survey Professional Paper 1646

Purkerson DG, Doblin MA, Bollens SM, Luoma SN, Cutter GA (2003) Selenium in San Francisco Bay zooplankton: Potential effects of hydrodynamics and food web interactions. Estuaries 26, 956-969

Richens DT (1997) The chemistry of aqua ions. Wiley, Chichester, UK

Roberge PR (2008) Corrosion Engineering: Principles and Practice. McGraw-Hill Professional

Schlekat CE, Dowdle PR, Lee BG, Luoma SN, Oremland RS (2000) Bioavailability of particleassociated selenium on the bivalve Potamocorbila amuresis. Environ Sci Technol 34: $4504-4510$

Simmons DB, Wallschlaeger D (2005) A critical review of the biogeochemistry and ecotoxicology of selenium in lotic and lentic environments. Environ Toxicol Chem 24:1331-1343

Staicu LC, van Hullebusch ED, Oturan MA, Ackerson CJ, Lens PNL (2014a) Removal of colloidal biogenic selenium from wastewater. Water Res (submitted)

Staicu LC, Ackerson CJ, Hunter WJ, Cornelis P, Ye L, Noblitt SD, Henry CS, Lens PNL, Cappa JJ, Montanieri R, Berendsen RL, Pilon-Smits EAH (2014b) High selenium reduction capacity in a Pseudomonas moravinsis strain endophytic to selenium hyperaccumulator Stanleya pinnata. Syst Appl Microbiol (in preparation)

Trompette JL, Vergnes V, Coufort C (2008) Enhanced electrocoagulation efficiency of lyophobic colloids in the presence of ammonium electrolytes. Colloid Surface A 315:6673

Turchiuli C, Fargues C (2004) Influence of structural properties of alum and ferric flocs on sludge dewaterability. Chem Eng J 103(1-3):123-131

US EPA Test Methods for Evaluating Solid Waste, Physical/Chemical Methods, SW-846, Method 1311. http://www.epa.gov/osw/hazard/testmethods/sw846/pdfs/1311.pdfUS 
EPA Test Methods for Evaluating Solid Waste, Physical/Chemical Methods, SW-846, Method 1311, Chapter 7 - Characteristics, introduction and regulatory definitions. http://www.epa.gov/wastes/hazard/testmethods/sw846/pdfs/chap7.pdf

US EPA (2010) North San Francisco Bay selenium characterization study plan (2010-2012). http://www2.epa.gov/sites/production/files/documents/epa-r09-ow-2010-0976-00231.pdf

Un UT, Koparal AS, Ogutveren UB (2009) Hybrid processes for the treatment of cattleslaughterhouse wastewater using Al and Fe electrodes. J Hazard Mater 164:580-586

USEPA (1999) Enhanced coagulation and enhanced precipitative softening guidance manual. EPA 815-R-99-012

Vasudevan S, Lakshmi J, Sozhan G (2009) Studies on the removal of iron from drinking water by electrocoagulation - A clean process. Clean 37:45-51

Vasudevan S and Oturan MA (2014) Electrochemistry: as cause and cure in water pollutionan overview. Environ Chem Lett 12:97-108

Zhang Y, Zahir ZA, Frankenberger Jr WT (2004) Fate of colloidal-particulate elemental selenium in aquatic systems. J Environ Qual 33:559-564

Zhu B, Clifford DA, Chellam S (2006) Comparison of electrocoagulation and chemical coagulation pretreatment for enhanced virus removal using microfiltration membranes. Water Res 13:3098-3108 


\section{TABLE CAPTIONS}

Table 1 Properties of biogenic Se(0) solution produced by a P. fluorescens strain (Growth conditions: $28^{\circ} \mathrm{C}$; $160 \mathrm{rpm} ; \mathrm{pH}_{0}=7.5$; aerobic; incubation time, $24 \mathrm{~h}$ )

Table 2 Summary of the EC results using Al and Fe sacrificial electrodes

Table 3 Summary of Se-Fe and Se-Al sediment characteristics 
Table 1 Properties of biogenic Se(0) solution produced by a $P$. fluorescens strain (Growth conditions: $28^{\circ} \mathrm{C}$; $160 \mathrm{rpm} ; \mathrm{pH}_{0}=7.5$; aerobic; incubation time, $24 \mathrm{~h}$ )

\begin{tabular}{ll}
\hline Parameter & Value \\
\hline Turbidity (NTU) & $500 \pm 30$ \\
Se $\left(\mathrm{mg} \mathrm{L}^{-1}\right)$ & $310 \pm 12$ \\
Color & Red \\
pH & $7.0 \pm 0.2$ \\
Conductivity $\left(\mathrm{mS} \mathrm{cm}^{-1}\right)$ & $4.5 \pm 0.2$ \\
Zeta potential $(\mathrm{mV})$ & $-20 \pm 2$ \\
\hline
\end{tabular}


Table 2 Summary of the EC results using Al and Fe sacrificial electrodes

Fe electrodes

\begin{tabular}{ccccccccc}
\hline $\begin{array}{c}\mathrm{I} \\
(\mathrm{mA})\end{array}$ & $\begin{array}{c}\mathrm{j} \\
\left(\mathrm{mA} \mathrm{cm}^{-2}\right)\end{array}$ & $\mathrm{U}(\mathrm{V})$ & $\begin{array}{c}\text { Removal } \\
\text { efficiency } \\
(\%)\end{array}$ & $\begin{array}{c}\text { Residual } \\
\text { turbidity } \\
(\mathrm{NTU})\end{array}$ & $\begin{array}{c}\mathrm{Fe}_{\text {theo }} \\
\left(\mathrm{g} \mathrm{L}^{-1}\right)\end{array}$ & $\begin{array}{c}\mathrm{E} \\
\left(\mathrm{kWh} \mathrm{m}^{-3}\right)\end{array}$ & $\begin{array}{c}\mathrm{C}_{\text {electrode }} \\
\left(\mathrm{kg} \mathrm{m}^{-3}\right)\end{array}$ & $\begin{array}{c}\mathrm{M}_{\text {sediment }} \\
\left(\mathrm{kg} \mathrm{m}^{-3}\right)\end{array}$ \\
\hline 50 & 0.83 & 1.4 & 69 & 157 & 0.1 & 0.14 & 0.104 & 17.4 \\
100 & 1.67 & 2.3 & 81 & 95 & 0.21 & 0.46 & 0.208 & 39.2 \\
200 & 3.33 & 3.9 & 97 & 16 & 0.42 & 1.56 & 0.417 & 61.6 \\
300 & 5.00 & 5.1 & 97 & 18 & 0.63 & 3.06 & 0.625 & 71.8 \\
500 & 8.33 & 7.9 & 96 & 20 & 1.04 & 7.9 & 1.042 & 84.5 \\
\hline
\end{tabular}

Notes: Fe theoretical, $\mathrm{Fe}_{\text {theo }}\left(\mathrm{mg} \mathrm{L}^{-1}\right)$; Electrical energy consumption, $\mathrm{E}\left(\mathrm{kWh} \mathrm{m}{ }^{-3}\right)$; Electrode consumption, $C_{\text {electrode }}\left(\mathrm{kg} \mathrm{m}^{-3}\right)$; Mass of sediment, $\mathrm{M}_{\text {sediment }}\left(\mathrm{kg} \mathrm{m}^{-3}\right)$ were determined after $60 \mathrm{~min}$ of electrolysis

\section{Al electrodes}

\begin{tabular}{ccccccccc}
\hline $\begin{array}{c}\mathrm{I} \\
(\mathrm{mA})\end{array}$ & $\begin{array}{c}\mathrm{j} \\
\left(\mathrm{mA} \mathrm{cm}^{-2}\right)\end{array}$ & $\begin{array}{c}\mathrm{U} \\
(\mathrm{V})\end{array}$ & $\begin{array}{c}\text { Removal } \\
\text { efficiency } \\
(\%)\end{array}$ & $\begin{array}{c}\text { Residual } \\
\text { turbidity } \\
(\mathrm{NTU})\end{array}$ & $\begin{array}{c}\mathrm{Al}_{\text {theo }} \\
\left(\mathrm{g} \mathrm{L}^{-1}\right)\end{array}$ & $\begin{array}{c}\mathrm{E} \\
\left(\mathrm{kWh} \mathrm{m}^{-3}\right)\end{array}$ & $\begin{array}{c}\mathrm{C}_{\text {electrode }} \\
\left(\mathrm{kg} \mathrm{m}^{-3}\right)\end{array}$ & $\begin{array}{c}\mathrm{M}_{\text {sediment }} \\
\left(\mathrm{kg} \mathrm{m}^{-3}\right)\end{array}$ \\
\hline 50 & 0.83 & 1.9 & 71 & 151 & 0.03 & 0.19 & 0.034 & 32 \\
100 & 1.67 & 2.6 & 86 & 86 & 0.07 & 0.52 & 0.067 & 76 \\
200 & 3.33 & 4.2 & 88 & 61 & 0.13 & 1.68 & 0.134 & 150 \\
300 & 5.00 & 5.7 & 96 & 22 & 0.2 & 3.42 & 0.201 & 212 \\
500 & 8.33 & 8.5 & 95 & 25 & 0.33 & 8.5 & 0.336 & 376 \\
\hline
\end{tabular}

Notes : Al theoretical, $\mathrm{Al}_{\text {theo }}\left(\mathrm{mg} \mathrm{L}^{-1}\right)$; Electrical energy consumption, $\mathrm{E}\left(\mathrm{kWh} \mathrm{m}^{-3}\right)$; Electrode consumption, $C_{\text {electrode }}\left(\mathrm{kg} \mathrm{m}^{-3}\right)$; Mass of sediment, $\mathrm{M}_{\text {sediment }}\left(\mathrm{kg} \mathrm{m}^{-3}\right)$ were determined after $60 \mathrm{~min}$ of electrolysis 
Table 3 Summary of Se-Fe and Se-Al sediment characteristics

\begin{tabular}{ccccccc}
\hline $\begin{array}{c}\text { I } \\
(\mathrm{A})\end{array}$ & $\begin{array}{c}\text { Volume } \\
(\mathrm{mL})^{\mathrm{a}}\end{array}$ & $\begin{array}{c}\text { Volume } \\
(\mathrm{mL})^{\mathrm{b}}\end{array}$ & $\begin{array}{c}\text { Mass } \\
(\mathrm{g})^{\mathrm{a}}\end{array}$ & $\begin{array}{c}\text { Mass } \\
(\mathrm{g})^{\mathrm{b}}\end{array}$ & $\begin{array}{c}\text { Density } \\
(\mathrm{g} / \mathrm{mL})^{\mathrm{a}}\end{array}$ & $\begin{array}{c}\text { Density } \\
(\mathrm{g} / \mathrm{mL})^{\mathrm{b}}\end{array}$ \\
\hline 0.05 & 5 & 11 & 9 & 16 & 1.74 & 1.45 \\
0.1 & 12 & 28 & 20 & 38 & 1.64 & 1.36 \\
0.2 & 24 & 58 & 31 & 75 & 1.28 & 1.29 \\
0.3 & 31 & 82 & 36 & 106 & 1.16 & 1.29 \\
0.5 & 38 & 170 & 42 & 188 & 1.11 & 1.11 \\
\hline
\end{tabular}

${ }^{\mathrm{a}} \mathrm{Fe}$-Se sediment

${ }^{\mathrm{b}} \mathrm{Al}-\mathrm{Se}$ sediment 


\section{FIGURE CAPTIONS}

Fig. 1 Schematic diagram of the electrocoagulation set-up. $M=$ metal (e.g. $\mathrm{Al}, \mathrm{Fe}), \mathrm{n}^{+}=$ oxidation state; $\mathrm{M}(\mathrm{OH})_{\mathrm{n}}=$ metal hydroxides.

Fig. 2 (a) Colloidal stability of biogenic red Se(0) produced by $P$. fluorescens. Evolution of the ratio $C / C_{0}$ in function of treatment time with $C_{0}$ and $C$ the turbidity in NTU unit at the initial and a giving time, respectively, (b) Biogenic red Se(0) produced by $P$. fluorescens and the control sample (KB medium).

Fig. 3 Variation of theoretical and measured Al and Fe with the electrical charge passed during EC. Operating conditions: temperature, $20^{\circ} \mathrm{C}$; volume, $0.5 \mathrm{~L}$; supporting media, 42 mmol L $\mathrm{L}^{-1}$ of $\mathrm{NaCl} ; \mathrm{pH}_{0}=7.0 ; 300 \mathrm{rpm}$; electrolysis time, $60 \mathrm{~min}$. $\mathrm{Fe}_{\text {theo }}$ and $\mathrm{Al}_{\text {theo }}$ refer to the theoretical metal dissolved according to Faraday's law (Eq. (6)). $\mathrm{Fe}_{\mathrm{m}}$ and $\mathrm{Al}_{\mathrm{m}}$ are the measured values with charge passed.

Fig. 4 (a) Turbidity removal, (b) pH evolution for Fe and Al electrodes. Note that the dashed lines in panel (a) represent residual turbidity (NTU). Operating conditions: temperature, 20

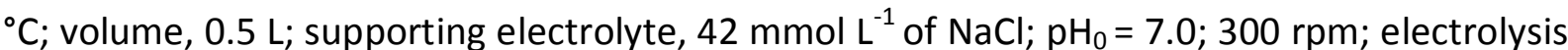
time, $60 \mathrm{~min}$.

Fig. 5 (a) TCLP of Se-Al and Se-Fe sediments (b) Residual Se in the supernatant of Al and Fe electrode experiments. Note that "zero" mA corresponds to the initial Se content of the suspension before EC treatment (c) Residual Al and Fe from the supernatant of $\mathrm{Al}$ and Fe electrode experiments.

Fig. 6 Sediment analysis: ESEM micrographs of (a) Se-Al sediment (500 nm scale), (b) Se-Fe sediment (500 nm scale), (c) XRD diffractogram of Se-Al sediment, (d) XRD diffractogram of Se-Fe sediment. Note: the sediments analyzed were produced at $100 \mathrm{~mA}$ under the following 
conditions (Conditions: Se(0) turbidity, $500 \mathrm{NTU}$; temperature, $20^{\circ} \mathrm{C}$; supporting media, 42 $\mathrm{mmol} \mathrm{L}{ }^{-1} \mathrm{NaCl} ; \mathrm{pH}_{0}=7.0 ; 300$ rpm; electrolysis time, $60 \mathrm{~min}$ ), (e) Evolution of Al-Se and Fe-Se sediment volume. Note that the volume of the treated solution was $500 \mathrm{~mL}$.

Fig. 7 Electrical energy consumption in $\mathrm{EC}$ of $\mathrm{Se}(0)$ with $\mathrm{Al}$ or Fe electrodes. 


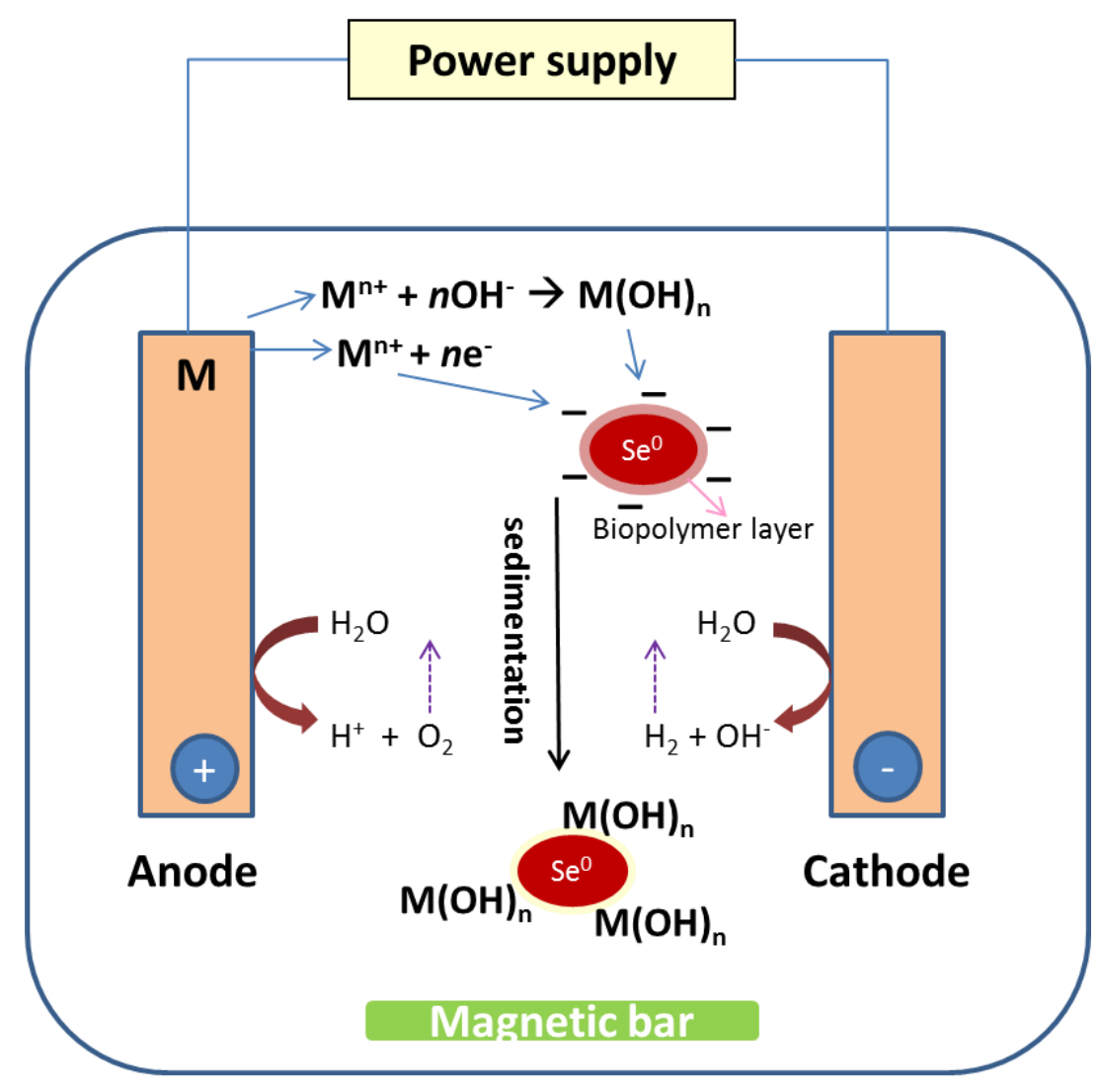

Fig. 1 Schematic diagram of the electrocoagulation set-up. $M=$ metal (e.g. Al, Fe), $n^{+}=$ oxidation state; $\mathrm{M}(\mathrm{OH})_{\mathrm{n}}=$ metal hydroxides. 


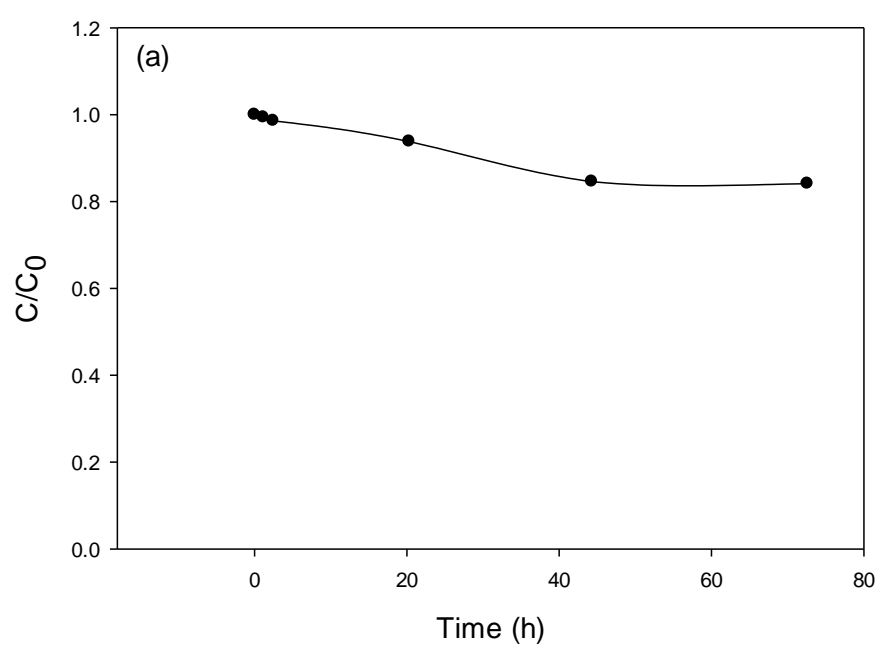




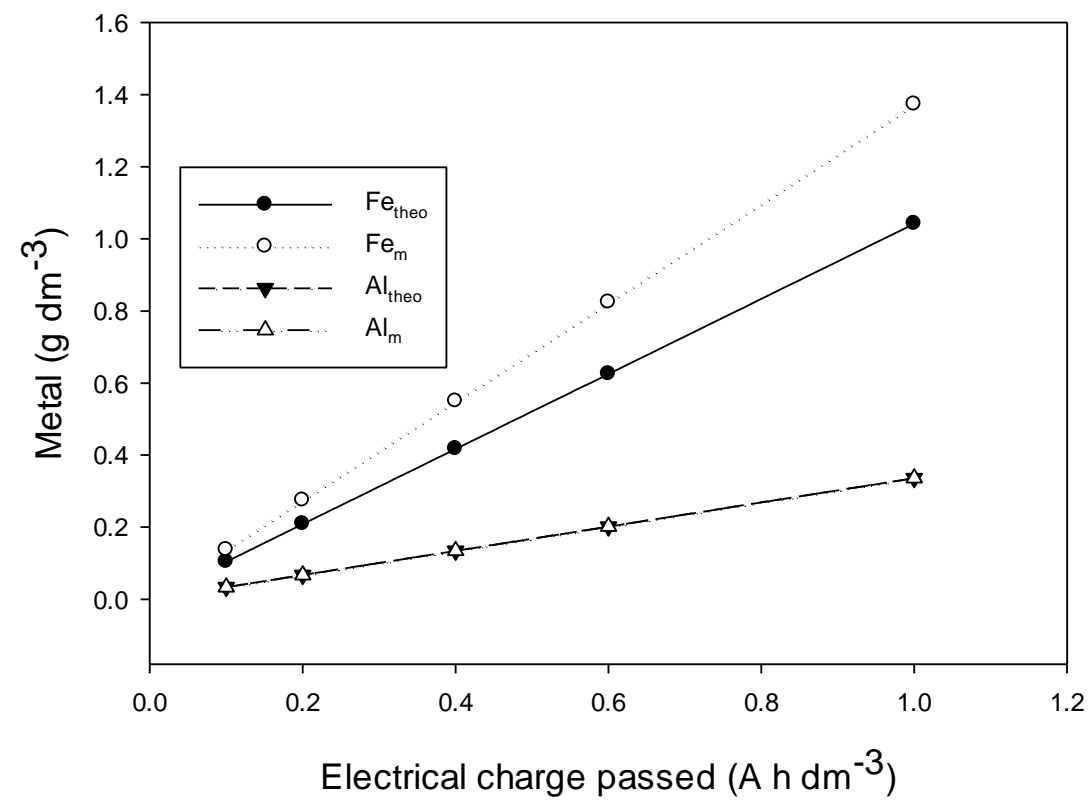

Fig. 3 Variation of theoretical and measured $\mathrm{Al}$ and Fe with the electrical charge passed during EC. Operating conditions: temperature, $20{ }^{\circ} \mathrm{C}$; volume, $0.5 \mathrm{~L}$; supporting media, 42 $\mathrm{mmol} \mathrm{L}^{-1}$ of $\mathrm{NaCl} ; \mathrm{pH}_{0}=7.0 ; 300 \mathrm{rpm}$; electrolysis time, $60 \mathrm{~min}$. Fe theo and $\mathrm{Al}_{\text {theo }}$ refer to the theoretical metal dissolved according to Faraday's law (Eq. (6)). $\mathrm{Fe}_{\mathrm{m}}$ and $\mathrm{Al}_{\mathrm{m}}$ are the measured values with charge passed. 

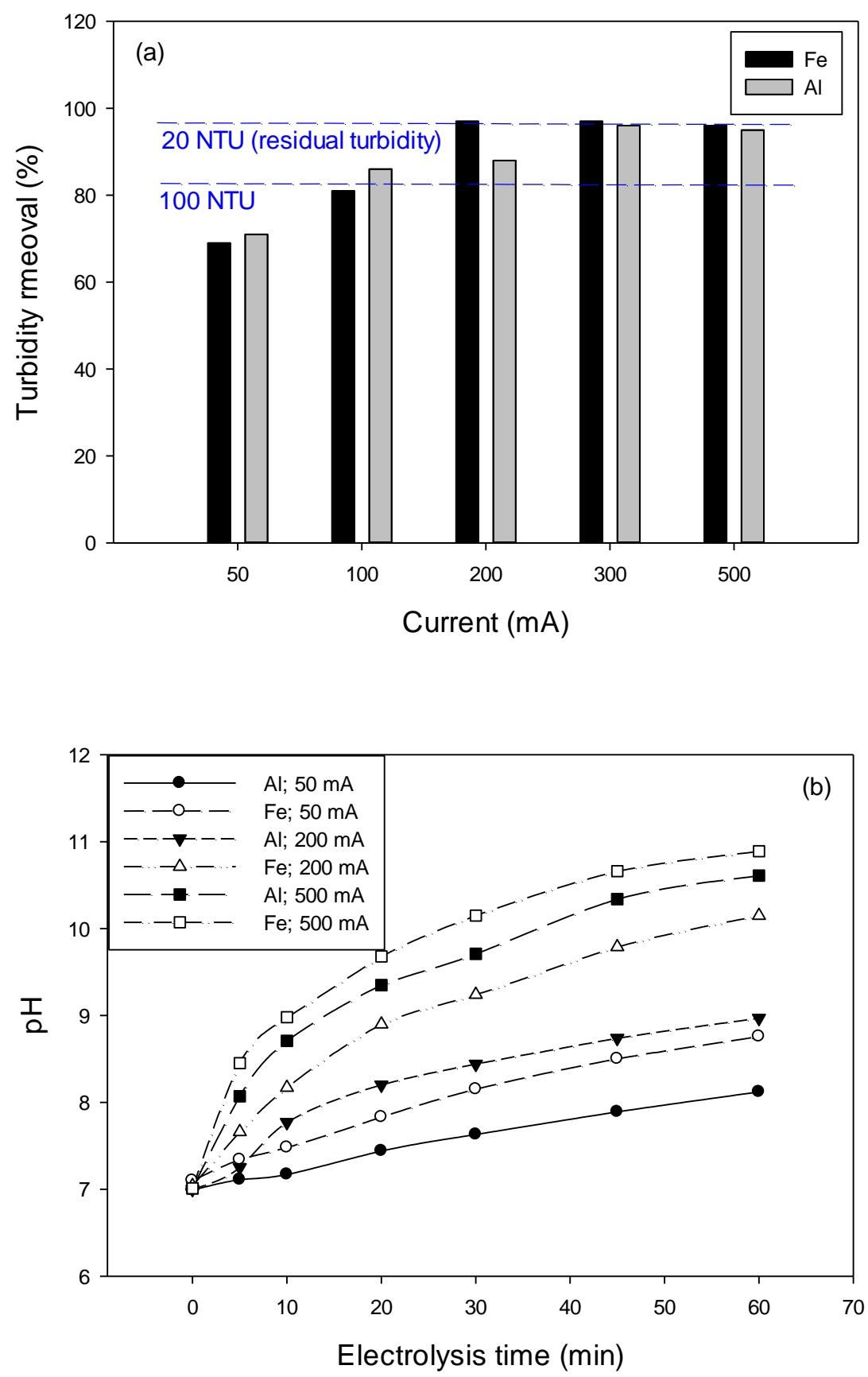

Fig. 4 (a) Turbidity removal and (b) pH evolution for Fe and Al electrodes. Note that the dashed lines in panel (a) represent residual turbidity (NTU). Operating conditions: temperature, $20^{\circ} \mathrm{C}$; volume, $0.5 \mathrm{~L}$; supporting electrolyte, $42 \mathrm{mmol} \mathrm{L}{ }^{-1}$ of $\mathrm{NaCl} ; \mathrm{pH}_{0}=7.0 ; 300$ rpm; electrolysis time, $60 \mathrm{~min}$. 

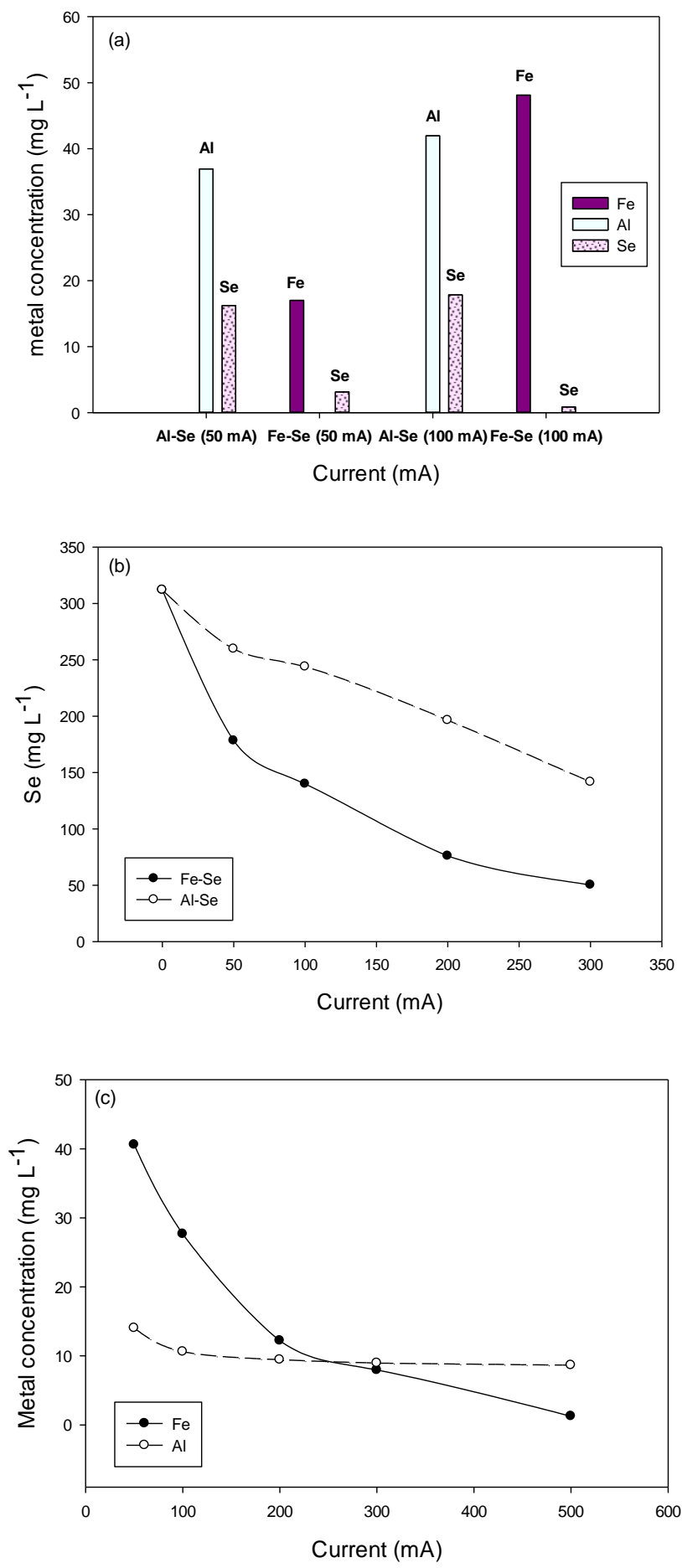

Fig. 5 (a) TCLP of Se-Al and Se-Fe sediments (b) Residual Se in the supernatant of Al and Fe electrode experiments and (c) Residual $\mathrm{Al}$ and Fe from the supernatant of $\mathrm{Al}$ and Fe electrode experiments. Note that "zero" mA corresponds to the initial Se content of the suspension before EC treatment 

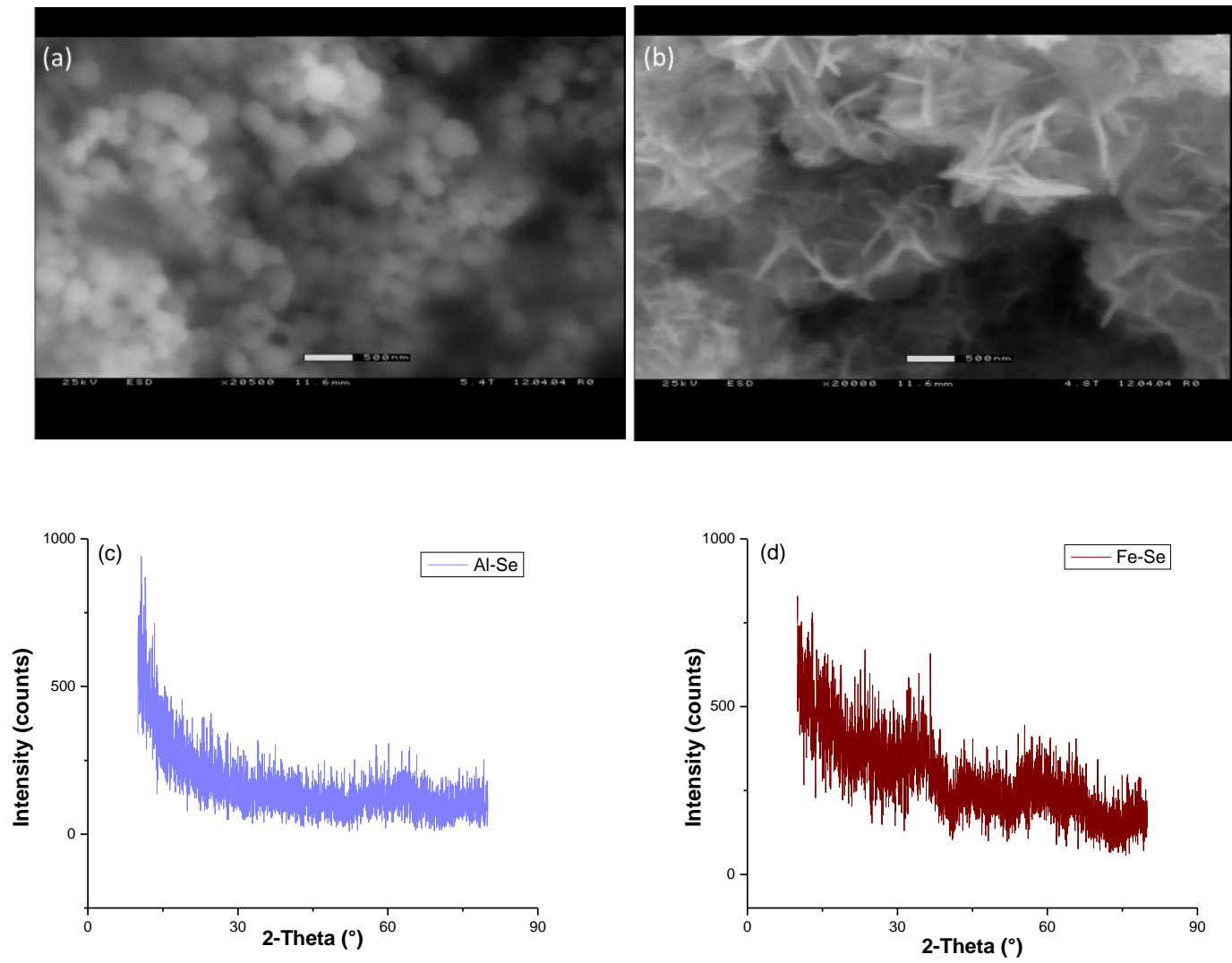

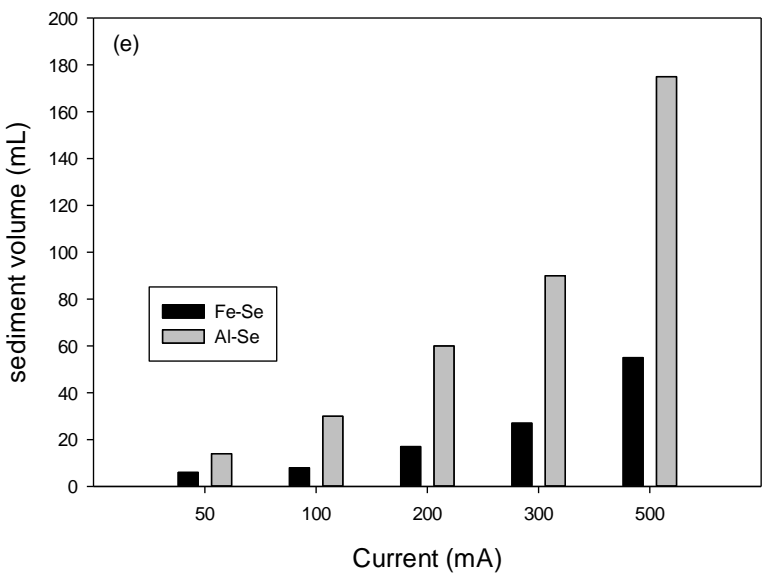

Fig. 6 Sediment analysis: ESEM micrographs of (a) Se-Al sediment (500 nm scale), (b) Se-Fe sediment (500 nm scale), (c) XRD diffractogram of Se-Al sediment, (d) XRD diffractogram of Se-Fe sediment. Note: the sediments analyzed were produced at $100 \mathrm{~mA}$ under the following conditions (Conditions: $\mathrm{Se}(0)$ turbidity, $500 \mathrm{NTU}$; temperature, $20^{\circ} \mathrm{C}$; supporting media, $42 \mathrm{mmol} \mathrm{L}^{-1} \mathrm{NaCl}$ p $\mathrm{pH}_{0}=7.0 ; 300 \mathrm{rpm}$; electrolysis time, $60 \mathrm{~min}$ ), (e) Evolution of Al-Se and Fe-Se sediment volume. 


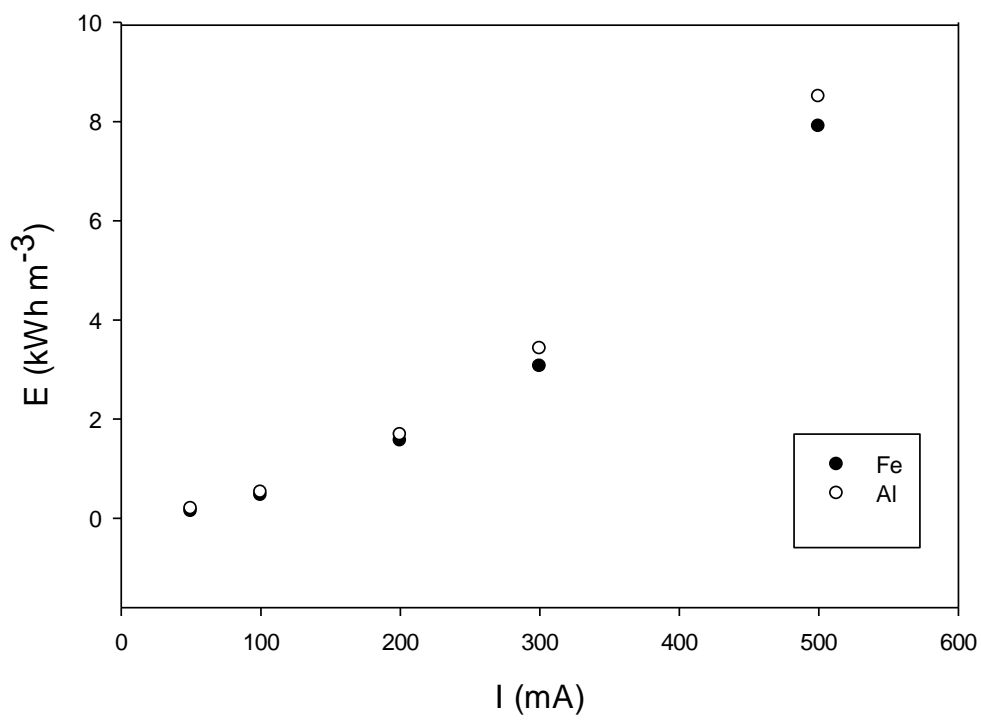

28

29

30

31

32

33

34

35

36

37

38

39

40

41

42

43

44

45

46

47

48

49

50

51

52

53

54

55

56

57

58

59

60

61

62

63

64

65

Fig. 7 Electrical energy consumption in EC of Se(0) with Al or Fe electrodes. 